\title{
Risk Detection of Curly Red Chili (Capsicum annum L) Production with House of Risk
}

\author{
Sri Ayu Andayani ${ }^{1 *}$, Silvianita ${ }^{1}$ and K. Somantri ${ }^{1}$ \\ Date Received: 14 ${ }^{\text {th }}$ December 2019 / Date Accepted: $26^{\text {th }}$ January 2020
}

\begin{abstract}
Purpose: In the phenomena and constraints faced by red chili farmers that result in unsustainable production, an interesting research question raised is how to detect production risks in curly red chili, the impact of risks caused by the source of risk and mitigation of priorities that must be done in managing risks which occurred in one of the red chili production centers in Majalengka Regency, West Java Province.

Research Method : Research to mitigate production risk is carried out using the House of Risk method at the red chili production center with 30 respondents. Respondents were determined purposively. Observed responses include risk events, risk agents to identify problems. The risk status grouping is determined based on the aggregate risk potential (ARP) value.

Findings : The results showed that curly red chili farming had 17 risk events with 7 risk agents. The risk agent for climate change and erratic weather produces the highest ARP value of around 3469 or around $30.33 \%$ so that this agent is considered to be the main priority in risk mitigation. Priority mitigation strategies can be carried out through the creation of green houses, training and application of standard operating procedures.
\end{abstract}

Limitations : Detecting event and sources on the risk red chili production.

Value : With detection of events and sources of risk it can produce priority potency for handling of risk or mitigation of risk.

Keywords: Production Risk, Curly Red Chili Farming, Risk Mitigation

\section{INTRODUCTION}

Climate change has caused various problems in various lives including agriculture. The climate in Indonesia has experienced changes associated with the occurrence of El-Nino Southem Oscillation (ENSO), and this affects and even hinders the performance of the agricultural sector (Boer et al., 2014). Supari et al., explained that changes in weather patterns during the warm ENSO period, prolonged drought, and the delay in the rainy season resulted in higher and more vulnerable agricultural risks (Supari et al., 2017). Climate change and pest attacks have a negative impact on the agricultural sector (Mashiza, 2019), especially horticulture such as red chili and shallots (Zuhriyah, 2012). The unsustainable supply of red chili from production centers to the market fluctuates quite high and influences inflation (Andayani, 2016). On the other hand red chili including curly red chili has the potential to be developed because it has high economic value (The Ministry of Agriculture of the Republic of Indonesia (MoA), 2015). The same thing was explained by Bank Indonesia because red chili tends not to know the season. Bank Indonesia has initiated to develop a red chili cluster in Indonesia since 2011 but until now it has not been optimal and still leaves problems including the large number of risks that occur (Bank Indonesia, 2015).

\footnotetext{
1 Faculty of Agricultural Universitas Majalengka, West Java, Indonesia.

sriayuandayani@unma.ac.id
}

D ORCID http://orcid.org/0000-0002-9807-3034 
Andayani explained in his research that the red chili agribusiness cluster in Garut Regency, West Java indicated production risks, market risks, and institutional risks that accumulated into financial risks (Andayani, 2015). In their research, Anwarudin et al., explained that there are strategies in dealing with the fluctuations in the price of red chili, such as by increasing the area of planting and production in the rainy and dry seasons, stabilizing prices, and developing reliable and sustainable partnership institutions (Anwarudin et al., 2015). Research by Wijaya et al., highlights chili in terms of post-harvest. Anticipating the deteriorating performance of the handling of the post-harvest chili, they proposed a quality plan through the selection of harvest time, adequate equipment in the presence of protective, packaging, transportation, and storage (Wijaya et al,2013). Conditions in the red chili cluster in handling post-harvest red chillies are still experiencing problems. Productivity to maintain the continuity of supply of red chili in addition to the technical aspects of cultivation that refers to standard operating procedures (SOP), can also be increased by taking into account the human resources they have, the level of independence of young agribusiness actors (PMA) which is relatively weak, especially in terms of quality and power competitiveness, as well as suggesting several collaborative strategies (Setiawan et al., 2015). Not only vegetables are affected by climate change but fruit producers in various countries often experience various risks associated with climate change and weather (Tsyr-Shuay, 2018). To reduce the negative impact of agricultural risk and reduce risk, small farmers are willing to pay insurance for agricultural production. In anticipation of climate change, the government implemented insurance of production costs in 2015 (a large number of subsidies have been allocated by the government) but the level of farmer participation is still very low (Mutaqin et al., 2019). Types of risk-prone agriculture due to climate change have very large variations (Arbuckle, 2015). Farmers around the world face and manage various risks caused by various factors (Duong et al., 2019). In the agricultural sector, not only is the weather climate a risk agent but there are also many opportunities related to plant disease pests and there are many risk-free opportunities in improving pest control by managing ecosystem services (Roos, et al., 2018).

Based on the phenomena and constraints faced by red chili farmers that result in unsustainable production, an interesting research question raises is how to detect production risks in curly red chili, the impact of risks caused by the source of risk and mitigation of priorities that must be done in managing risks which occurred in one of the red chili production centers in Majalengka Regency, West Java Province.

\section{METHOD}

The study was designed in a descriptive quantitative and qualitative manner with a case study method designed to describe the risks and sources of risk that are the problem. The steps taken are to explore the causes of production discontinuity and offer alternative solutions to mitigate the risk. The used analysis in analyzing the level and impact of risk on curly red chilli farming is the House of Risk (HOR) Method. HOR is a modification of the development of the Failure Mode and Effect Analysis (FMEA) and adapts the House of Quality (HOQ) to be able to prioritize which risks are handled first so that they can choose the most effective actions in managing risks.

The HOR method can be used to proactively manage risk. Risk agents identified as causes of risk events can be managed by ranking them on the basis of the magnitude of the impact that is likely to occur. The stages in the HOR method, namely, HOR 1 and HOR 2. The framework in the HOR1 stage is carried out to determine the choice of risk agents as a priority in subsequent risk prevention (Rizqiah, 2017). The stages of the HOR model are: HOR 1 (a). Identify the occurrence of risk (risk event, Ej) and assess the severity (severity, SJ), (b). Identify the risk agent (Aj) and assess the level of frequency (Oj) for the likelihood to occur, (c). Providing a correlation value (Rij) between risk events and risk (d). Calculating the aggregate risk potential (ARPj) determined by the likelihood of the occurrence of risk agents and the aggregate 
impact of the risk events incurred (e). Making risk agent priorities based on potential aggregate risks. HOR 2 gives priority proactive steps that effectively reduce the risk based on financial capabilities and other resources. HOR 2 can also be used to facilitate management in prioritizing risk management that has been identified and calculated the level of risk in HOR (Rizqiah, 2017). HOR steps 2 (a). Determine several risk agents with top ranking to be the cause of the risk that will be prioritized to be addressed (b). Identify relevant proactive action (PAk) steps to prevent risk agents (c). Determine the level of relationship between each PA and risk agent $(E j k)(d)$. Calculate the total effectiveness of each proactive action $T E_{K}=\sum A R P_{j} . E_{j k}(\mathrm{e})$. Assess the level of difficulty (Dk) in implementing PA (f). Calculate the ratio of total effectiveness to the level of difficulty $E T D_{k}=T E_{k} / D_{k}(\mathrm{~g})$. Give priority to the list of proactive actions that are most effective in reducing the occurrence of risk according to ability.

\section{RESULTS AND DISCUSSIONS}

\section{Risks in curly red chili plants}

Table 01 provides data on risk events ranging from seeding, cultivation, harvesting, postharvesting as well as marketing to be marked with a code to facilitate the detection process.

Risk agents can be said to be the cause of a risk event. Table 02 is a list of risk agents as a possible cause of the risk of crop failure in curly red chilli farming. Selection of the seeds, climate change, and erratic weather are likely to fail in the high red chili farming.

Table 01: $\quad$ List of Production Risk Events

\begin{tabular}{llc}
\hline Curly Red Chili Farming Process & \multicolumn{1}{c}{ Event Risk } & Code \\
\hline Nursery & Sprout sprouts & E1 \\
& Grow not synchronously & E2 \\
& Pests in the ground & E3 \\
& Growing media & E4 \\
& Treatment & E5 \\
\hline Cultivation & Planting & E6 \\
& Maintenance & E7 \\
& Falling flower & E8 \\
& die of withering & E9 \\
& attacked by pests & E10 \\
& stricken with disease & E11 \\
& low flowering & E12 \\
\hline Harvest and post harvest & Crop failure & E13 \\
& Sorting & E14 \\
& Processing yield & E15 \\
\hline Marketing & sell directly to the market & E16 \\
& sell to merchant collectors & E17 \\
\hline
\end{tabular}

Table 02: $\quad$ List of Agents and Possible Risk

\begin{tabular}{clcc}
\hline Code & \multicolumn{1}{c}{ Risk Agent } & Occurrence & Possibility of Failure \\
\hline A1 & Seed selection & 8 & Very high \\
A2 & Climate change and erratic weather & 8 & Very high \\
A3 & Postharvest without technology & 7 & High \\
A4 & Nature of chili that is easily damaged & 7 & High \\
A5 & Price unable to compete & 6 & Medium \\
A6 & Lack of manpower & 6 & Medium \\
A7 & HR negligence in maintenance & 7 & High \\
\hline
\end{tabular}


Table 03: $\quad$ Risk Agent ARP Value and Mitigation Priority Ranking Sequence

\begin{tabular}{ccccccc}
\hline No. & Code & ARP & Level & \% ARP & \% ARP Cumulative & Category \\
\hline 1 & A2 & 3469 & 1 & 30,33 & 30,71 & Priority \\
2 & A7 & 3208 & 2 & 28,05 & 58,76 & 75,90 \\
\hline 3 & A1 & 1960 & 3 & 17,14 & 85,68 & \\
4 & A4 & 1118 & 4 & 9,78 & 91,51 & Non Priority \\
5 & A3 & 667 & 5 & 5,83 & 96,49 & \\
6 & A5 & 570 & 6 & 4,98 & 100,38 & \\
7 & A6 & 444 & 7 & 3,88 & & \\
\hline
\end{tabular}

The influence or impact of the greatest risk agent on the activity of curly red chilli farming can be seen from its ARP value. A risk agent that has a high ARP value means it has a large impact on farming activities of curly red chili and vice versa. The results of calculation of all ARP values can be seen in Table 03 .

Climate change and erratic weather are risk agents that have a big influence and become the main priority in handling. This is not much different from the results of Tan et al.,'s research that in the agricultural sector the risks are related to weather $(55 \%)$, risks related to human resources (35\%), the rest are related to other factors.

The determination of priority risk agent categories is done using the Pareto law or the 80:20 law. Determination of priority risk agent categories can be seen in Figure 01. Figure 01 explains that the main priority to get treatment is the risk agent for climate change and erratic weather (A2), negligence risk agent for human resources in maintenance (A7), and the agent seed selection risk (A1). That is because the
ARP value of each risk agent has the greatest value among the other risk agent ARP values.

The results of the calculation of ARP value of risk agents in curly red chilli farming is shown in the Table 04.

\section{Mitigation Strategies Used for Handling Occurring Risks}

Measurements for mitigation strategies for risk agents can be analyzed by HOR 2 . At this stage, identification of appropriate and accurate treatment strategies to reduce priority risk agents is proposed. The priority risk agents for handling or mitigating are climate change and erratic weather, negligence of human resources in maintaining and selecting seedlings. Mitigation actions are: (1). climate and weather adjustments (PA1), (2). making green houses (PA2), (3). improving farmers' skills (PA3), (4). training related to Good Agriculture Practices (GAP) ( PA4), (5). application of Operational Standards for Curly Red Chili Farming Procedure (PA5), (6). selection of quality red chili superior seeds (PA6).

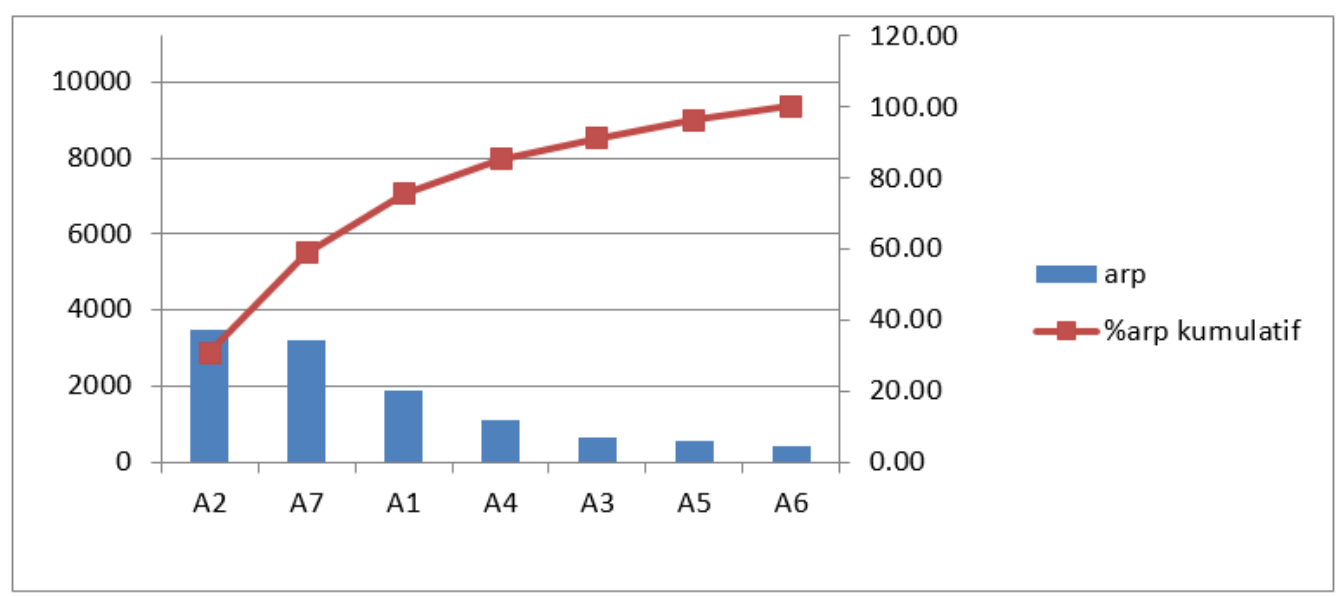

Figure 01: Pareto Diagram of Risk Agents in Curly Red Chili Farms 
Table 04: $\quad$ Results of Correlation Values and ARP Values in Curly Red Chili Farms

\begin{tabular}{ccccccccc}
\hline Code & A1 & A2 & A3 & A4 & A5 & A6 & A7 & Sj \\
\hline E1 & 9 & 3 & & 1 & & 1 & 3 & 7 \\
E2 & 9 & 3 & & & 1 & & 9 & 5 \\
E3 & 1 & 3 & & & & & 3 & 5 \\
E4 & 1 & & & & & & & 5 \\
E5 & & 3 & & 1 & & 1 & 3 & 7 \\
E6 & 3 & 3 & & & 3 & & 3 & 6 \\
E7 & 1 & 9 & & & & 3 & 9 & 6 \\
E8 & 3 & 9 & & & & & 3 & 5 \\
E9 & 3 & 9 & & & & & 9 & 6 \\
E10 & 3 & 9 & & 3 & 1 & & 9 & 8 \\
E11 & 3 & 9 & & 3 & 1 & & & 8 \\
E12 & 3 & 3 & & & & & 9 & 5 \\
E13 & 1 & 3 & & 3 & 3 & 3 & 9 & 9 \\
E14 & & & 3 & 3 & 3 & & 3 & 5 \\
E15 & & & 9 & & 3 & 3 & 1 & 5 \\
E16 & & & 3 & 9 & & & & 3 \\
Code & A1 & A2 & A3 & A4 & A5 & A6 & A7 & Sj \\
E17 & & & 9 & 9 & & & & 3 \\
Oj & 8 & 8 & 7 & 7 & 6 & 6 & 7 & \\
ARP & 1960 & 3469 & 667 & 1118 & 570 & 444 & 3208 & \\
Pj & 3 & 1 & 5 & 4 & 6 & 7 & 2 & \\
\hline
\end{tabular}

Mitigation actions are identified, then Total The calculation results explain that the value Effectiveness (TE) and Difficulty level (D) obtained is the highest value of the mitigation calculations are calculated. The final stage in the action ratio because the higher the value of the House of Risk (HOR2) is determining priority mitigation action ratio, the more effective the mitigation actions that can be implemented. mitigation action to be implemented. PA1 ETD Priority mitigation actions must be determined value is 8116 , so it can be said that mitigation by calculating the ratio between the value actions are more effective to be implemented of effectiveness and the value of the level of (because the value of the mitigation action ratio difficulty. A TE PA1 value of 40578 means that is the greatest value compared to the others). PA1 (climate and weather adjustments) has a The results of the calculation of mitigation high level of difficulty in handling or mitigating actions can be seen in Table 05 . actions. The greater the TE value, the more difficult it is to handle risk agents and vice versa.

Table 05 Mitigation Action Calculation Results

\begin{tabular}{clccccccc}
\hline Code & Risk Agent Description & PA1 & PA2 & PA3 & PA4 & PA5 & PA6 & ARP \\
\hline A2 & $\begin{array}{l}\text { Climate Change and } \\
\text { Erratic Weather }\end{array}$ & 9 & 9 & & & & & 3475 \\
A7 & $\begin{array}{l}\text { HR Negligence in } \\
\text { Maintenance }\end{array}$ & 3 & & 9 & 9 & 3 & 1 & 3101 \\
A1 & Seed Selection & & & & 1 & 3 & 3 & 1907 \\
& $\quad \mathrm{TE}$ & $\mathrm{H}(5)$ & $\mathrm{M}(4)$ & $\mathrm{M}(4)$ & $\mathrm{M}(4)$ & $\mathrm{L}(3)$ & $\mathrm{L}(3)$ & \\
& $\mathrm{D}$ & 8116 & 7819 & 6977 & 7454 & 5008 & 2941 & \\
\hline
\end{tabular}


In the Table 05, it is found that the highest value of mitigation actions is found in the PA1 variable of 40578 with a value of 5 . The calculation results show that the costs required for mitigation actions tend to be quite high or difficult to implement. Counseling to increase a better understanding of farmers' perspectives on climate change and weather needs to be done (Arbuckle et al., 2014). In a research in China's Anhui Suzhan City in avoiding risk, farmers made the decision to buy weather-based crop insurance. This can provide useful insights for local policy makers and insurance companies and can increase farmer participation in insurance (Jin et al., 2016).

\section{CONCLUSIONS}

From the survey results of the 30 farmers, there were 17 risk events with 7 risk agents.
The results of the HOR analysis show that the highest ARP value was 3469 or around 30.33\% which occurred in climate change and erratic weather. The results of this analysis will have a major effect and become the main priority in risk mitigation in red chili. The priority mitigation strategies can be created through the creation of green houses, training and application of operational standard procedures.

\section{Data Availability Statement}

The datasets generated during and/or analyzed during the current study are available from the corresponding author on reasonable request.

\section{ACKNOWLEDGMENT}

Author is thankful for Universitas Majalengka, West Java Indonesia

\section{REFERENCES}

Andayani, S.A, Sulistyowati Lies, Perdana Tomy (2016). The Development of Red Chili Agribusiness Cluster with Soft System Methodology Approach in Garut. Journal Mimbar Vol 32 No.2 Desember 2016 PP 302-310. ISSN 0215-8175 EISSN 2303-2499. DOI: https:// doi.org/10.29313/mimbar.v32i2.1861

Andayani, S.A. (2015). Model Kemitraan Klaster Agribisnis Cabai Merah untuk Mengelola Risiko. Pasca Sarjana Universitas Padjadjaran

Anwarudin J M, Apri L, Sayekti, Aditia Marendra K, Yusdar Hilman. (2015). Dinamika Produksi dan Volatilitas Harga cabai: Antisipasi strategi dan Kebijakan Pengembangan. Jurnal Pengembangan Inovasi Pertanian ISSN 1979-5378 492/Akred/P2MI-LIPI/08/2012 Vol 8 No 12015.

Arbuckle J Gordon, Jon Hobbs, A loy L.W Morton, L S Prokopy and J Tyndall. (2014). “Understanding Corn Belt Farmers' Perspectives On Climate Change to Inform Engagement Strategies for Adaptation and Mitigation". Journal of Soil and Water Conservations Vol 69 No 6 505-516. DOI: https://doi.org/10.2489/jswc.69.6.505

Arbuckle J Gordon, Jr Lois Wright Morton, Jon Hobbs. (2015). Understanding Farmers'Perspectives On Climate Change Adaptation and Mitigation: the Roles of Trust in Sources Of Climate Information, Climate Change Beliefs and Perceived Risk". SAGE Journal Environment and Behavior Vol 47 Issue 2, 205-234. 2015. DOI: https://doi.org/10.1177/0013916513503832

Bank Indonesia, (2015). Pengembangan Klaster Cabai Merah Garut

Boer, Rizaldi, and Yuli Suharnoto. (2014)." Climate Change Impact on Indonesia Food Crop". Paper presented at The Sixth Executive Forum on Natural Resource Management: Water \& Food in a Changing Environment at SEARCA Headquarters, Los Baños, The Philippines, April 11-13 
Duong Thi Tan, Tom Brewer, Jo Luck and Kerstin Zander. (2019). A Global Review Of Farmers'Perceptions Of Agricultural Risks and Risk Management Strategies. Journal Agriculture Vol 9 Issue 1. 2019. DOI: https://doi.org/10.3390/agriculture9010010

Jin JianJun, Wenyu Wang, Xiaomin Wang. (2016). Farmers' Risk Preferences and Agricultural weather Index Insurance Uptake in Rural China. International Journal of Disaster Risk Science December 2016. Vol 7 Issue 4 PP 366-373. DOI: https://doi.org/10.1007/s13753016-0108-3

Mashiza Tinashe M. (2019). Adapting to Climate Change: Reflections of Peasant Farmers In Mashonaland West Province Of Zimbabwe. JAMBA Journal of Disaster Risk Studies V11(1), 2019. DOI: https://doi.org/10.4102/jamba.v11i1.571

Mutaqin Dadang Jainal and Koichi Usami. (2019). Smallholder farmers Willingness to Pay For Agricultural Production Cost Insurance In Rural West Java Indonesia: A Contingent Valuation Methode (CVM) Approach. Graduate Scholl of International Development (GSID), Nagoya University. Nagoya 464-8601. Japan. DOI: https://doi.org/10.3390/risks7020069

Rizqiah Emielda. (2017). Manajemen Risikoi Supply Chain dengan Mempertimbangkan Kepentingan Stakeholder pada Industri Gula. Magister Teknik Industri ITS Surabaya. DOI: https://doi.org/10.21070/prozima.v1i2.1287

Roos Elin, Axel Mie, Maria Wivstad, Eva Salomon, Birgitta Johansson, Stefan Gunnarsson, Anna Wallenbeck, Ruben Hoffman, Ulf Nilsson, Cecilia Sundberg, Christine A Watson. (2018). Risk and Opportunities Of Increasing Yields In Organic Farming.A Review. Journal Agronomy For Sustainable Development Official Journal of The Institute National de La Recharche Agronomique (INRA).ISSN 1774-0746 (Print) 1773-0155 (Online) Pebruari 2018. DOI: https://doi.org/10.1007/s13593-018-0489-3

Setiawan Iwan, Sumardjo, Arif Satria, Prabowo Tjitropranoto. (2015). Strategi pengembangan Kemandirian Pelaku Muda Agribisnis" Brain Gain Actors" di jawa Barat. Mimbar Unisba Vol 31 No 2 Print ISSN 02158175 Online ISSN 2303-2499. Desember 2015. DOI: https:// doi.org/10.29313/mimbar.v31i2.1491

Supari, Ester Salimun, Elvin Aldrian, Ardhasena Sopaheluwakan, Liew Juneng, and Fredolin Tangang. (2017). ENSO Modulation of Seasonal Rainfall and Extremes in Indonesia. Climate Dynamics 51: 2559-80. DOI: https://doi.org/10.1007/s00382-017-4028-8

The Ministry of Agriculture of the Republic of Indonesia (MoA). (2015). The Description of Asuransi Usatani Padi (AUTP); Jakarta: The Ministry of Agriculture of the Republic of Indonesia.

Tsyr-Shuay, Jennifer E Ifft, Breadley J, Rickard and Calum G Turvey. (2018). Alternative Strategies to Manage Weather Risk in Perennial Fruit Crop Production. Agricultural and Resurce Economics Journal Review Vol 17 Issue 3 published online by Cambridge University Press 15 January 2018. DOI: https://doi.org/10.1017/age.2017.29

Wijaya, W Dwi, Sutapa Nyoman, (2013). Upaya Pengurangan Tingkat Kecacatan Cabai pasca Panen Pada Jalur Rantai Pasok. Jurnal Tirta Vol 1 No 2 pp 253-255.

Zuhriyah Amanatuz, Aminah Happy MA. (2012). Jurnal Rekayasa Of Science and Technology Vol 5 No 2 ISSN; 0216-9495. https:// journal.trunojoyo.ac.id/rekayasa 